\title{
Mesenchymal Stromal Cells in Pediatric Hematopoietic Cell Transplantation a Review and a Pilot Study in Children Treated With Decidua Stromal Cells for Acute Graft-versus-Host Disease
}

\section{OPEN ACCESS}

Edited by:

Robert James Hayashi, Washington University School of Medicine in St. Louis, United States

Reviewed by: Astrid Gertrude Suzanne Van Halteren, Leiden University Medical Center, Netherlands

Frederic Baron,

University of Liège, Belgium

*Correspondence: Olle Ringdén Olle.ringden@ki.se

Specialty section:

This article was submitted to Alloimmunity and Transplantation,

a section of the journal

Frontiers in Immunology

Received: 29 May 2020 Accepted: 02 September 2020 Published: 19 October 2020

Citation:

Ringdén $O$, Gustafsson $B$ and Sadeghi B (2020) Mesenchymal Stromal Cells in Pediatric Hematopoietic Cell Transplantation a Review and a Pilot Study in Children Treated With Decidua Stromal Cells for Acute Graft-versus-Host Disease.

Front. Immunol. 11:567210. doi: 10.3389/fimmu.2020.567210

\author{
Olle Ringdén ${ }^{1 *}$, Britt Gustafsson ${ }^{2}$ and Behnam Sadeghi ${ }^{1}$ \\ ${ }^{1}$ Translational Cell Therapy Research (TCR), Division of Pediatrics, Department of Clinical Science, Intervention and \\ Technology (CLINTEC), Karolinska Institutet, Stockholm, Sweden, ${ }^{2}$ Division of Pediatrics, CLINTEC, Karolinska Institutet, \\ Stockholm, Sweden
}

Mesenchymal stromal cells (MSCs) are rare precursors in all organs of the body. MSCs have profound anti-inflammatory effects and reduce alloreactivity in vitro and in vivo. In pediatric allogeneic hematopoietic cell transplantation (HCT), MSCs have mainly been used to treat acute graft-versus-host disease (GVHD). MSCs are commercially available for this indication in Canada, Japan, and New Zeeland. More rare indications for MSCs in pediatric patients include graft failure and chronic GVHD. MSCs from bone marrow, adipose tissue, umbilical cord, Wharton's jelly, placenta tissue, and decidua have been used, but the optimal clinical stromal cell source has not been compared in clinical trials. More experimental clinical indications using MSCs, such as sepsis, acute respiratory distress syndrome, hemorrhages, pneumo-mediastinum, and neuroinflammation have primarily been explored in animal models or adult HCT patients. MSCs have almost no if any side-effects. In this pilot study we report the outcome of six children treated with decidua stromal cells (DSCs) for steroid refractory acute GVHD. At 6 months, complete response was seen in four patients and partial response in two patients. One child with high-risk ALL died from relapse and a boy with sickle cell disease died from a cerebral hemorrhage. Five-year survival was $67 \%$ and all survivors showed a Lansky score of $100 \%$. To conclude, MSCs from various organs are well-tolerated and have shown an encouraging outcome for acute GVHD in pediatric patients.

Keywords: graft-versus-host disease (GVHD), mesenchymal stromal cell (MSC), pediatric haematopoietic stem cell transplantation, cell theraphy, decidua stromal cells (DSCs)

\section{INTRODUCTION}

Hematopoietic cell transplantation (HCT) is an established treatment for children with both malignant and non-malignant hematopoietic diseases and inborn errors of metabolism (1-4). The main obstacles to success are relapse of the disease, infections, graft failure, toxicity of various organs, hemorrhagic cystitis, and graft-versus-host disease (GVHD). To prevent GVHD, patients 
are treated with immunosuppressive drugs, most commonly, calcineurin inhibitor combined with Methotrexate (5). Despite this, a majority of the patients developed acute GVHD, with a considerable mortality, even if this was significantly lower in children compared to adults (6). To confirm the gastrointestinal GVHD histopathological biopsies is recommended, since e.g., viruses could cause gastrointestinal symptoms (7-9). Cortisone is first-line therapy for acute GVHD (10) and almost all immunosuppressive therapies are used as a secondary treatment with varying degrees of success (11). Friedenstein et al. were the first to describe MSCs (12). We introduced mesenchymal stromal cells (MSCs) as a new therapy for acute $\operatorname{GVHD}(13,14)$. MSCs are rare in all tissues in the body and can differentiate into several cells of mesenchymal cell lineages, such as bone, cartilage, tendon, cardiomyocytes, muscles, and fat $(15,16)$. There is no specific CD marker for MSCs. However, they stain positive for CD29, CD73, CD90, CD105, and CD166. They are negative for hematopoietic markers, CD34, CD45, and CD14. They are not true stem cells because they cannot regenerate and maintain a whole tissue compartment. MSCs express HLA class I molecules and contain intracellular HLA class II that is expressed on the cell surface after interferon- $\gamma$ stimulation (17). After injection, MSCs do not appear to be long lived and have been demonstrated in the circulation only shortly after infusion into patients who underwent autologous HCT for breast cancer (18).

\section{IMMUNOSUPPRESSION}

MSCs have potent immunomodulatory effects and inhibit phytohemagglutinin induced $\mathrm{T}$ cell proliferation and alloreactivity in mixed lymphocyte cultures (MLC) $(17,19,20)$. MSCs' inhibition of alloreactivity in vitro is independent of the major histocompatibility system (21). Furthermore, after differentiation into osteocytes, chondrocytes and adipocytes, immunosuppression was still induced (17). MSCs also prolonged skin allograft survival in baboons (19). Several factors and mechanisms are involved in MSC-mediated immune modulation.

Bone marrow MSCs (BM-MSCs) are susceptible to complement activation after contact with human blood (22). This results in cell dysfunction or cell death (23). When in contact with blood, BM-MSCs also elicit activation of clotting factors (24).

MSC immunosuppression has been studied extensively (25-28). Stromal cells from various organs such as BM, Wharton's jelly, placenta tissues and cord blood have varying immunosuppressive effects in the $\operatorname{MLC}(17,19-$ 21, 29, 30). The MLC is also inhibited by skin fibroblasts (31). Immunosuppressive factors produced by MSCs include prostaglandin E2 (32), HLA-G5 (33), and galectins (34). MSCs also produce indoleamine-2,3, dioxygenase (IDO), which inhibits $\mathrm{T}$ cells by converting of tryptophan to kynurenine [(35), Figure 1]. IDO is involved in the induction of regulatory $\mathrm{T}$ cells and the inhibition of Th17 differentiation (36). IDO produced by MSCs also promotes differentiation of macrophages toward M2 phenotypes (37). MSCs also induce contact-dependent immunosuppression. Among these are activation of the PD-1 pathway (38), by activation of VCAM-1 and ICAM-1 (39), purification of CD39 and increased adenosine production (40), and Fas-mediated T-cell apoptosis (41). There are differences in various species and, in mice, several models failed to reduce alloreactivity and GVHD (42). To inhibit GVHD in mice, MSCs need to be licensed by IFN- $\gamma$, nitric oxide, or transduced with IL10 to prevent GVHD. In a colitis model in mice, it was shown that prevention of colitis by MSCs requires $\mathrm{CD} 11 \mathrm{~b}+$ macrophages (43). In a murine model of GVHD, it was demonstrated that MSCs are actively induced to undergo perforin-dependent apoptosis by recipient cytotoxic T-cells, and that this process is essential to initiate MSCinduced immunosuppression (44). After IV infusion, recipient phagocytes engulf apoptotic MSCs and produce IDO, which is necessary for immune suppression. MSCs produce exosomes and microparticles, some of which are small complexed entities that contain both immunomodulatory proteins, micro RNA and mediators for homing abilities (45). Exosomes were also used to reverse acute GVHD (46).

\section{MESENCHYMAL STROMAL CELLS FOR TREATMENT OF ACUTE GVHD}

We introduced MSCs, as a therapy for acute GVHD, by treating a 9-year-old boy with life-threatening grade IV acute GVHD, as well as a phase-I study in GVHD patients whom were resistant to several immunosuppressive therapies $(13,14)$. We also performed a multi-center phase II study, including 55 patients with severe steroid resistant GVHD (47). Complete responders had lower transplantation-related mortality 1 year after infusion than patients with partial or no response (11 [37\%] of 30 vs. 18 [72\%] of 25; $p=0.002$ ). Patients with complete response to MSCs had a 2-year survival of $53 \%$ as opposed to $16 \%$ in partial and non-responders. Children had a trend for better response (64\%) as opposed to adults (47\%). Subsequently, several single-center studies were performed with varying results using various sources of stromal cells, for instance, adipose tissue (48). Lucchini et al. gave platelet lysate expanded MSCs to children with severe steroid refractory acute or chronic GVHD with varying responses (49). Commercial MSCs (prochymal) were given to 12 children with therapy-resistant grade III and IV acute GVHD (50). A complete response was seen in seven children (58\%), a partial response in two (17\%), and mixed responses were recorded in three $(25 \%)$ of the children. The 100 -day survival was 58\%. Osiris performed a double-blind placebo controlled phase 2/3 study using prochymal for severe acute GVHD (51). The children were given $8 \times 10^{6} \mathrm{MSCs} / \mathrm{kg}$ twice a week or placebo. Among 260 patients, including children and adults, who were randomized in this trial, a complete response at 28 days was $74 \%$ in the MSCs group and 30\% in the placebo group (52). However, the 180-day durable response of liver GVHD was $29 \%$ in the MSC group compared to $5 \%$ in the placebo group $(p=0.047 \%)$. Among patients with acute GVHD grades III-IV, Remestemcell-L demonstrated significantly higher overall response, $65 \%$, as opposed to $23 \%$ in the placebo $\operatorname{arm}(p=$ 


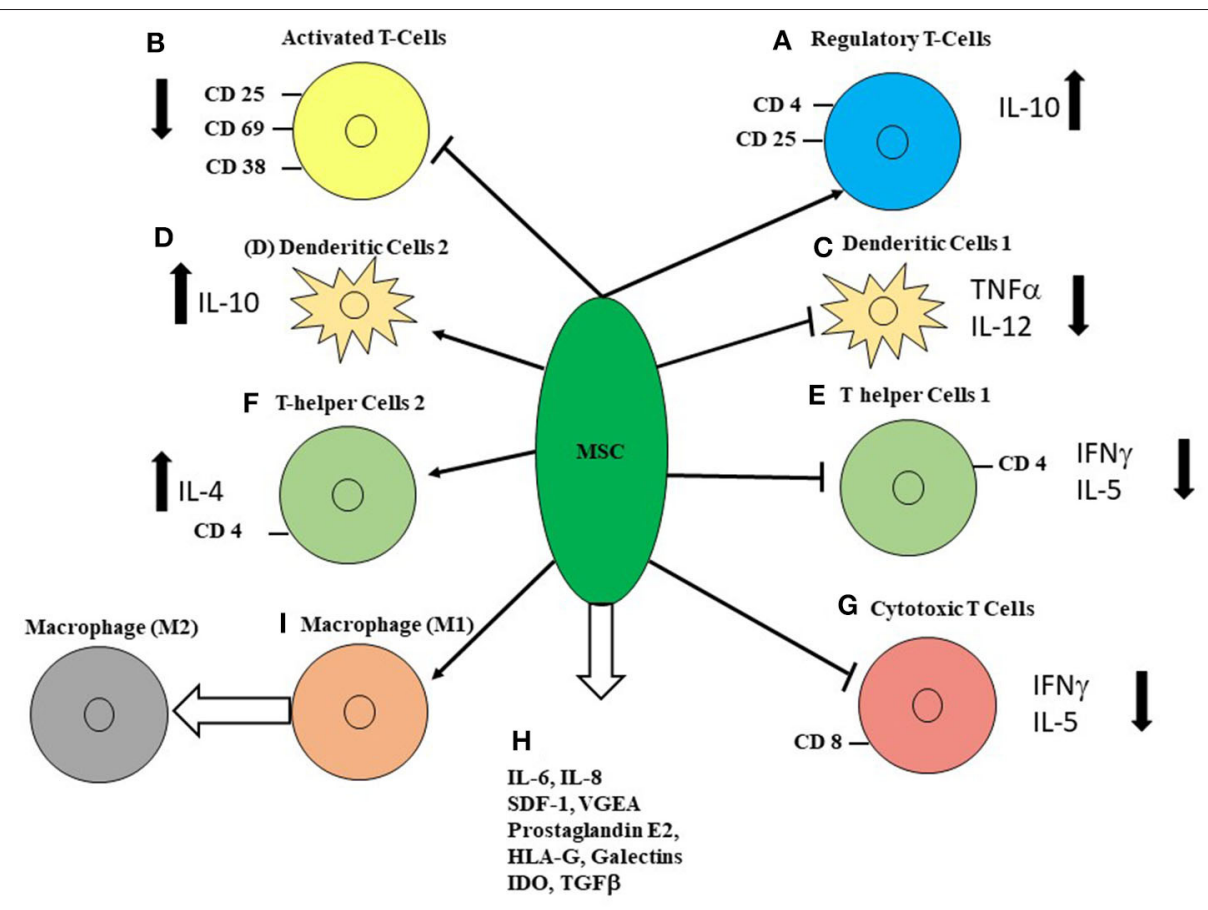

FIGURE 1 | The multiple effects of MSCs on immune cells. (A) MSCs increase the proportion of CD4+CD25+ cells and IL-10 production. (B) MSCs decrease markers for activated T cells, CD25, CD69, and CD38. MSCs delayed maturation of APC and decreased expression of HLA-DR. (C) Dendritic cell type 1 when stimulated had decreased TNF- $\alpha$ and IL-12, when co-cultured with MSCs. (D) MSCs increased IL-10 secretion by LPS-stimulated dendritic cells type 2, CD4+ cell had decreased IL5-secretion. (E) T-helper cell type 1 IFN- $\gamma$ production was significantly decreased by MSCs. (F) T-helper cell type 2 increased IL-4 secretion in the presence of MSCs. (G) MSCs inhibit mixed lymphocyte cultures and subsequent development of cytotoxic $\mathrm{T}$ cells by a soluble factor. (H) Several soluble factors are produced by MSCs, amongst them are IL-6, IL-8, stem-cell derived factor 1 (SDF1), vascular endothelial growth factor (VEGF). Soluble factors that have been suggested to inhibit T-cell activation are prostaglandin E2, which induces regulatory T-cells, indoleamine 2,3-dioxygenase (IDO), which is induced by IFN- $\gamma$ which catalyzes the conversion from tryptophan to kynurenine and inhibits T-cell responses. Other soluble factors that have been suggested to inhibit T-cell responses are TGF $\beta 1$, hepatocyte growth factor and IL-2. (I) MSC induce macrophage differentiation from M1 to M2. (References are mentioned in the text).

0.05). Children had a better outcome of treatment with MSCs for acute GVHD as compared to adults. These pediatric patients were also reported separately (53). Ball and coworkers reported on 37 children treated with MSCs for steroid-refractory grade III-IV acute GVHD (54). A response was observed in 65\% of the children. The 3-year survival was $37 \%$. Kurtzberg et al. reported on 241 children with steroid refractory acute GVHD who were treated for 4 weeks with infusion of $2 \times 10^{6} \mathrm{MSCs} / \mathrm{kg}$ (Remestemcel-L) twice weekly (55). The overall response rate at day +28 was $65 \%$. Survival at 100 days was $82 \%$ among the responders and $39 \%$ among the non-responders $(p \leq 0.001)$. In a Brazilian multicenter study, involving 16 children and 30 adults with steroid refractory GVHD, half of the patients responded and 1-year survival was $20 \%$ (56). A study using platelet-lysateexpanded MSC for steroid refractory acute GVHD included eight children and 22 adults. The overall response rate at day +28 was $50 \%$ in the adults and $88 \%$ in the children $(p=0.099)$. The survival was $88 \%$ in the children as opposed to $25 \%$ in the adults $(p=0.003)$ (57).

A study used BM-MSCs pooled from multiple third-party donors (58). The study included 92 adult and pediatric patients with steroid refractory acute GVHD. The patients received a median of three doses of pooled MSCs without toxicity. The overall response was $82 \%$ and 6 -month survival was $64 \%$. In a previous separate analysis of children, the overall response at day 28 was $77 \%$ and the 2 -year survival was $77 \%$ (59). At our unit, long-term follow up of patients treated with BM-MSCs with steroid refractory GVHD included nine children and 22 adults (60). Two-year survival was only $26 \%$. Patients receiving MSCs from passage 1-2 had significantly better survival than those receiving MSCs from passage 3-4 $(p<0.01)$. A meta-analysis reported that children had a better response to MSCs therapy for steroid refractory acute GVHD, with an overall response rate of $82 \%$, as opposed to $70 \%$ in adults $(p=0.04)(61)$. A more recent meta-analysis included children and adults given MSCs for prophylaxis $(n=651)$ and for treatment of acute GVHD $(n=$ 149) and chronic GVHD ( $n=76)$ (62).

\section{MESENCHYMAL STROMAL CELLS FOR TREATMENT OF CHRONIC GRAFT-VERSUS-HOST DISEASE}

Chronic GVHD is a great burden for many patients after HCT $(63,64)$. It seems logical to use MSCs to treat chronic GVHD, which resembles auto-immune disorders. MSCs were reported to be successful in many models of autoimmune diseases $(65,66)$. There are only a few reports on MSCs for chronic GVHD and 
most are about adults $(14,67,68)$. Lucchini et al. used plateletslysate expanded MSCs in four children with chronic GVHD (49). Transient benefits were noted. One child had a complete response that subsequently re-flared.

DSCs appear to have a stronger immunosuppressive effect than MSCs from bone marrow $(30,69)$. Thus, we used DSCs to treat chronic GVHD in three pediatric patients with severe grade 3 chronic GVHD (Based on National Institute of Health, $\mathrm{NIH})(70)$. The three pediatric patients were affected in several organs such as the skin, mouth, eyes, gastrointestinal tract, liver, lungs and joints, fascia. Two patients received two doses of DSC and one patient received one dose. Two patients had a partial response in the liver, normalization of elevated liver enzymes and, in one patient, esophageal varices disappeared. However, the overall grading of chronic GVHD remained very severe (3) according to NIH grading (71). A meta-analysis of 76 children and adults with chronic GVHD suggested improved survival using MSCs (62).

\section{PREVENTION OF GVHD AND GRAFT FAILURE}

In mice, MSCs were shown to prevent the development of lethal GVHD (72). Lazarus et al. performed co-transplantation of HLA-identical sibling bone marrow and donor MSCs in 46 patients (73). No patient had graft failure and grades III-IV acute GVHD were seen in $15 \%$ of the patients. We performed co-transplantation of HCT and MSCs to enhance engraftment (74). All patients had engraftment and full donor chimerism. A prospective randomized study of HCT and with co-infusion of MSCs or placebo reported decreased risk of acute GVHD and increased likelihood of relapse (75). Engraftment of neutrophils and platelets was similar in the two groups. Most studies of co-transplantation of HCT and MSCs are performed in adult patients or in a combination of pediatric and adult patients $(76,77)$. In a pediatric study, parental haplo-identical MSCs were used to promote engraftment in unrelated donor umbilical cord blood transplantation (78). In another pediatric study, MSCs were given to recipients of haplo-identical grafts (79). No patient had graft failure as opposed to $10 \%$ of the retrospective controls. A meta-analysis, which included 651 children and adults, showed improved survival in patients treated with MSCs as prophylaxis (62). MSCs may also be used to treat graft failure $(80,81)$.

\section{MSCs FOR METABOLIC DISORDERS}

Hurler's disease is deficiency of the enzyme alfa-L-iduronidase. HCT may partially prevent disease progression if performed before the patient is 2 years of age $(82,83)$. HCT patients with Hurler's disease and metachromatic leukodystrophy were given MSCs to enhance enzyme production after HCT (84). The rationale for using MSCs was because these cells express high levels of alpha-L-iduromidase and arylsulphataseA. Four out of five patients with metachromatic leukodystrophy had improved nerve conduction velocity. Five patients with osteogenesis imperfecta who underwent HCT had donor osteoblast engraftment, new dense bone, increased total bone mineral content and improved growth velocity (85). The frequency of bone fractures decreased. Gene-marked MSCs were given to six HCT patients with MSC engraftment in bone and accelerated growth velocity. In a fetus with bilateral femur fractures due to severe osteogenesis imperfecta, in utero transplantation of MSCs showed 7\% engraftment and the patient had fewer fractures than expected after birth (86).

\section{MSCs FOR HEMORRHAGES AND SIDE-EFFECTS}

We used MSCs for hemorrhagic cystitis, colon perforation, and pneumomediastinum after HCT (87). Adult patients are more vulnerable and had more toxicity after HCT as opposed to pediatric patients. However, toxicity also occurs in children with advanced hematological malignancies treated with multiple rounds of chemotherapy prior to transplantation. Stromal cells induce clotting and may stop or prevent bleeding. This effect appears to be stronger for DSCs than BM-MSCs (88). Yim et al. reported on two patients with pneumomediastinum/pneumothorax with resolution after MSCs treatment (89).

\section{MATERIALS AND METHODS}

\section{Patients}

Six children diagnosed with grade II-IV acute gastrointestinal GVHD, with or without skin involvement, were treated with DSCs (Table 1). The patients comprised five boys and one girl aged from 10 months to 16 years. Informed consent was obtained from the legal guardians of the patients. Diagnoses were pre-B-ALL in two children, Langerhans cell histiocytosis $(\mathrm{LCH})$, sickle cell anemia, osteopetrosis, and severe combined immunodeficiency (SCID). The conditioning therapy was total body irradiation and etoposide in the two patients with leukemia. The four children with other disorders were given fludarabine together with treosulfan in three patients and with the addition of thiotepa in one patient with sickle cell anemia. A boy with osteopetrosis was given a low dose of busulfan, in addition to fludarabine. Donors were matched unrelated in three patients, cord blood in two children, and bone marrow from an HLA-identical sibling donor in one patient. Posttransplant immunosuppression consisted of tacrolimus together with sirolimus in four patients (Table 1). Three patients were given antithymocyte globulin (90).

Acute GVHD was graded according to Seattle criteria (91). The diagnosis of gastrointestinal GVHD was based on biopsies from endoscopies (7-9). Skin biopsies were not performed. Donor recipient chimerism was followed by PCR and patients with acute GVHD were full-donor chimeras (9, 92). Cytomegalovirus (CMV) was followed weekly by PCR and reactivation was treated with ganciclovir (93). Epstein-Barr virus (EBV) PCR was only regularly followed in patients with an EBV-mismatched donor (94). Adenovirus was 


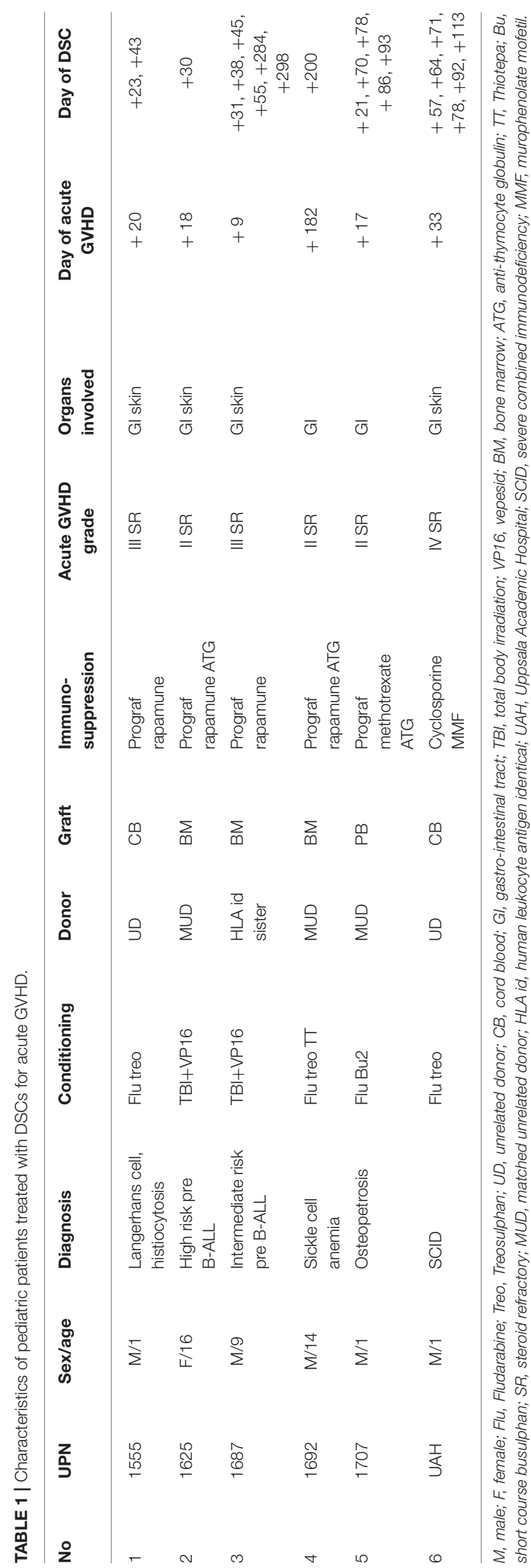

not monitored routinely (95), and only when an infection was suspected.

\section{Ethics}

We received ethical approval from the regional ethic committee to harvest DSCs from Caesarian section placentas and use them for treatment of GVHD and toxicity after HCT (2009/418-3134 and 2010/2061-32, 2010/452-31/4, and 2014-2132-32). The procedure for using DSCs was also later approved by the Central Ethical Review Board in Sweden (Dnr 011-2016). The method for clinical culture of DSCs was also approved by the Swedish Product Agency (Dnr 6.1.3-42994/2013).

\section{Decidua Stromal Cell Culture}

The method to culture and expand DSCs was previously published in detail (96). DSCs express CD166, CD105, CD73, CD44, and CD29. They did not express hematopoietic markers CD34, CD14, and CD45. DSCs were negative for bacteria, mycoplasma, and fungi before infusion. The DSCs were cultured and expanded in a good manufacturing process laboratory. DSCs were stored in liquid nitrogen, thawed, and resuspended in CliniMACS PBS/EDTA buffer, supplemented with $10 \% \mathrm{AB}$ plasma or $5 \%$ albumin (69). The cells were washed three times and resuspended in $\mathrm{NaCl}$ and $10 \% \mathrm{AB}$ serum or $5 \%$ albumin. The infusion solution was filtered through a $70 \mu \mathrm{M}$ cell strainer (BD Bioscience, Franklin Lakes, NI) before being transferred to a heparinized syringe (Leo Pharma, Ballerup, Denmark) at $2 \times$ $10^{6} \mathrm{cells} / \mathrm{ml}$. The DSC was infused intravenously using a central venous line. The central venous line was flushed with $2-5 \mathrm{~mL}$ of $\mathrm{NaCl}$ with $25 \mathrm{IE}$ heparin/ml in children weighing over $15 \mathrm{~kg}$ and 12.5 IE heparin/ml in children weighing under $15 \mathrm{~kg}$.

\section{RESULTS}

Patient 1 (UPN, unique patient number, 1555). A male baby boy was presented with disseminated LCH disease including bone marrow involvement and was pretreated with steroids and chemotherapy, followed by a HCT. The boy received an unrelated cord blood transplant. We previously reported that LCH can be cured by HCT $(97,98)$. Due to poor engraftment he was treated with granulocytes colony-stimulating factor (G-CSF) from day +20 after HCT. He reached absolute neutrophil counts (ANC) $>0.5 \times 10^{9} / \mathrm{L}$ on day +27 . On day +20 after HCT, he started vomiting and had watery diarrhea 10 times/day. His diarrhea deteriorated and he developed a skin rash on the back of his body. He was given high- dose prednisolone $(2 \mathrm{mg} / \mathrm{kg})$. Due to unresponsiveness he was treated with DSCs 3 days later and one additional dose was administered 3 weeks after the steroids had been introduced (Table 1). DSC doses were above $2 \times 10^{6} / \mathrm{kg}$ and viability was 78 and $95 \%$ in the two infusions, respectively (Table 2). At day 28 after DSC infusion, he had a partial response (PR). At day 56 and at the 6-month follow-up he showed no signs of acute GVHD (Table 2). He was diagnosed with a CMV reactivation on day +61 treated with ganciclovir. He is currently alive and well more than 8 years after HCT and from last follow up he showed Lansky score of $100 \%$. 


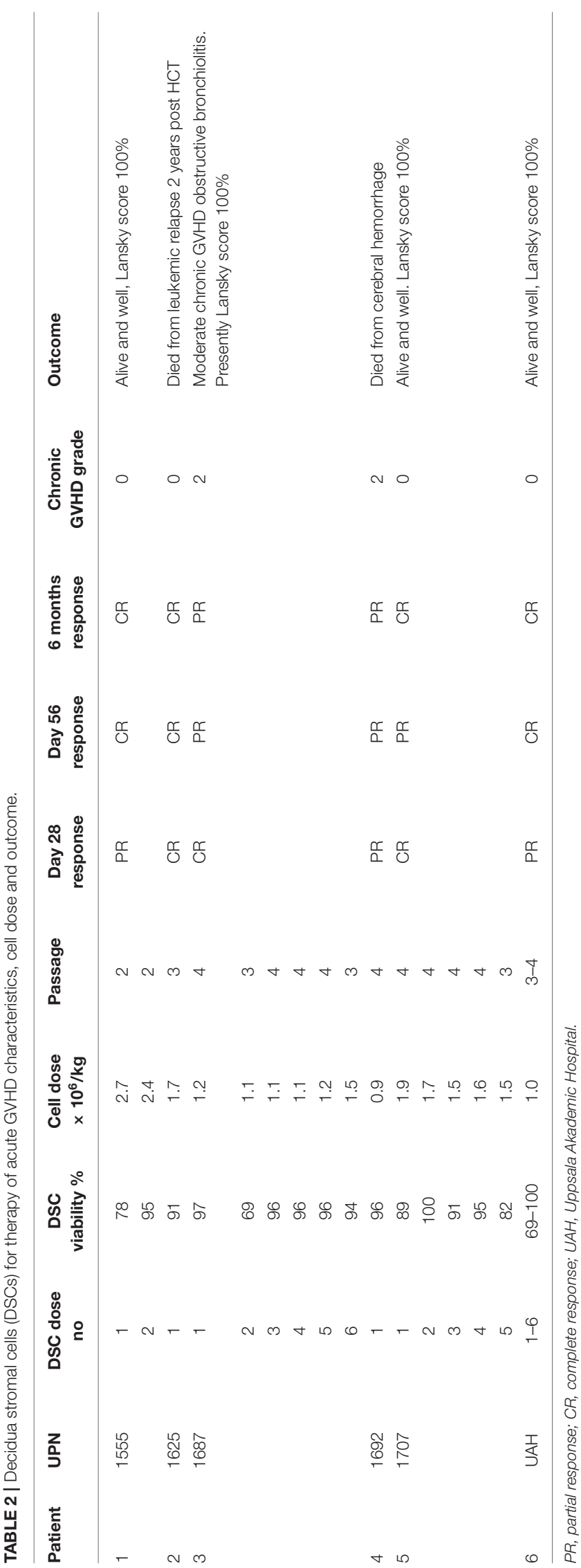

Patient 2 (UPN 1625). A 16-year-old female with high risk BALL in 2nd complete remission (CR) received bone marrow from an unrelated donor. The patient was treated pre-HCT according to the NOPHO (Nordic Pediatric Hematology Oncology) ALL protocol 2008 and was in complete remission pre HCT, including MRD $<0.01 \%$ (99). She experienced CMV reactivation on day +19 , treated with ganciclovir. ANC reached $>0.5 \times 10^{9} / \mathrm{L}$ on day +23 . Eighteen days post-transplant, she developed steroid refractory grade II acute GVHD of the gastro-intestinal tract and a skin rash. She was treated with a high dose of steroids from day +20 , but did not respond. Due to steroid resistance, she was treated with one dose of DSCs 30 days after HCT (Table 1). The DSC dose was $1.7 \times 10^{6} / \mathrm{kg}$ with $91 \%$ viability (Table 2 ). Her symptoms of acute GVHD disappeared and she was considered to be in a complete response at day 28 and remained so. However, the patient died from leukemic relapse 2 years after HCT.

Patient 3 (UPN 1687). A 9-year-old boy with an intermediate risk of B-ALL in CR2 received a bone marrow graft from his HLA-identical sister. He was previously treated according to the NOPHO ALL protocol 2008 (99). Both donor and recipient were CMV seropositive. He had no CMV reactivation. On day +10 he had hemorrhagic cystitis grade II that resolved. Already on day 9 after HCT he developed acute GVHD of the gastrointestinal tract and erythema of the skin. He did not respond to high doses of steroids and was considered steroid refractory. On day +30 he also developed a varicella-zoster reactivation. One month after HCT he was given $1.2 \times 10^{6} \mathrm{DSC} / \times 10^{6} / \mathrm{kg}$ with a viability of 97\% (Table 2). At day 28 after DSC treatment was initiated, he had complete resolution of all signs of acute GVHD but received another three additional weekly doses (Tables 1, 2). However, at 6 months, it was evident that he had developed signs of chronic GVHD as sicca and lichenoid changes of the skin, treated with extracorporeal psoralene and ultraviolet light (PUVA). After another 2 months he developed signs of a more generalized GVHD, with symptoms from both the skin, the liver, and the gastrointestinal tract. The biopsy from the GI-tract revealed GVHD, grade II (8) and he was given two more doses of DSC (Tables 1, 2). The symptoms of acute GI-GVHD disappeared but one and a half year after transplant he was still having symptoms of moderate chronic GVHD, mainly symptoms of bronchiolitis obliterans. 6.5 years after HCT he is suffering from NIH grade 2 chronic GVHD and is now treated with a JAK2 inhibitor, but from his last follow up he scored Lansky 100\%.

Patient 4 (UPN 1692). A 14-year-old boy arrived in Sweden, from an African country with an untreated severe sickle cell disease. He had a history of multiple sickle cell crises, as severe pain, osteonecrosis, cerebral infarctions, and bleedings and was therefore planned for a HCT. Before HCT he was treated with Hydrea capsules, but the treatment showed very moderate effect. He was finally transplanted and received bone marrow $(0.25 \times$ $10^{6} \mathrm{CD} 34+$ cells $/ \mathrm{kg}$ ) from an unrelated donor (12/12 match). He reached ANC $>0.5 \times 10^{9} / \mathrm{kg}$ on day +19 . On day +28 he was treated with acyclovir for a herpes simplex virus infection. Immunosuppression was tacrolimus combined with sirolimus. During discontinuation of immunosuppression on day $182 \mathrm{after}$ HCT he developed diarrhea diagnosed as gastrointestinal GVHD. Steroids were administered, but the diarrhea continued. One 
week later he was given $0.9 \times 10^{6} \mathrm{DSC} / \times 10^{6} / \mathrm{kg}$ (Table 2). He had a partial response at 28 days and at follow-up at 6 months. Seven months after HCT he had CMV reactivation treated with ganciclovir. One year after the transplant he developed chronic GVHD, NIH overall score 2 (Table 2). However, the patient died from severe cerebral hemorrhage 1 year and 9 months after HCT, where previous cerebral damage pre HCT probably contributed to cerebral hemorrhage post HCT.

Patient 5 (UPN 1707). A 1-year-old boy with osteopetrosis rejected the first graft and was re-transplanted 2 months later. He received a peripheral blood graft from an unrelated donor (Table 1). HLA-match was 10/12 with one antigen-HLA-C and -DP-mismatches. CD34+ cell dose was $34 \times 10^{6} / \mathrm{kg}$. He had $\mathrm{CMV}$ reactivation on day +11 , treated with ganciclovir. On day 17 after HCT he developed diarrhea grade II that did not respond to steroids. He was subsequently given five doses of DSC in doses ranging from 1.5 to $1.9 \times 10^{6} / \mathrm{kg}$ per $\mathrm{kg}$ (Table 2). The viability of the cells ranged from 82 to $100 \%$. At day 28 after initiation of DSC therapy, he had a complete response. At day 56 he had some abdominal pain and a loose stool. At the 6-month followup the stool was normal. He did not develop any chronic GVHD and is currently alive and well 6 years after transplantation, with a Lanskys score of $100 \%$.

Patient 6 The boy, born at term, non-consanguineous parents, was admitted to the hospital at the age of 9 months, with symptoms of severe respiratory infections, failure to thrive, and low lymphocytes. He was investigated for suspected severe combined immunodeficiency (SCID). Genetic analysis revealed a JAK-3 gene mutation (two heterozygous variants, leading to a frame shift and premature stop codon; p.Ser 449LysfsX71). At 12 months of age the boy was transplanted, with cord blood as a stem cell source. Pre-HCT the boy was colonized with rhinovirus, which also was observed after transplantation. On day 29, PCR-chimerism analysis revealed $60 \%$ donor cells. Subsequently, during immunosuppressive tapering, he developed a skin rash and, a few days later, also massive diarrhea due to gastrointestinal GVHD. This was diagnosed on a colon biopsy showing crypt destruction with several apoptotic bodies and regenerated features of grade IV gastrointestinal GVHD (8). He did not respond to steroids or mycophenolate mofetil therapy (Tables 1, 2). From day 57 after HCT, he was treated with weekly doses of DSCs. He had a partial response at day 28 and continued to need albumin transfusions. He received a total of six doses of DSCs before the resolution of gastrointestinal GVHD. At day 56 and 6 months after transplant he had a complete response and was doing well. Apart from rhinovirus, no viral, or fungal infections were diagnosed post-HCT. He is currently alive and well, 5 years after transplantation. He doesn't need any medications goes to school and shows Lanskys score of $100 \%$.

\section{Overall Follow Up}

The outcome among these six children treated for severe gastrointestinal and sometimes also acute skin GVHD at the 28-day follow-up was a complete response in three patients and a partial response in three patients (Table 2). At 6 months, a complete response was seen in four patients and a partial response in two patients. Two patients developed moderate chronic GVHD. One patient with high risk pre-B-ALL died of leukemic relapse 2 years after transplantation. A boy with sickle cell anemia died of cerebral hemorrhage 1 year and 1 month after HCT, although he had a history of multiple severe sickle cell crises before HCT. Three patients are alive and well and one patient is suffering from moderate chronic GVHD with obstructive bronchiolitis but responded to Jak-2 inhibition. Now he scores Lansky $100 \%$. Overall, there is a 5 -year survival of $67 \%$.

\section{DISCUSSION}

Although this is only a small series of pediatric patients treated for acute GVHD, it still holds some promise. None of the children died from GVHD and 6-year survival was four out of six (67\%). This is similar to what was achieved with DCSs with 21 patients, most of them older adults with a 4-year survival of $57 \%$ (100). The two deaths were due to relapse in the patient with highrisk ALL and cerebral hemorrhage in the patient with sickle cell disease. These are unfortunate yet expected complications after HCT. Patients who survived acute GVHD have an reduced risk of leukemic relapse (101). The graft-versus-leukemia (GVL) effect did not prevent relapse in this girl with high risk B-ALL. She did not develop chronic GVHD. The study from the International Registry suggested that acute GVHD had a profound GVL effect in ALL patients (102). A European study in ALL patients found that chronic GVHD was more important to decrease relapse probability (103). There were only two patients who developed moderate chronic GVHD. Children have a relatively low risk of chronic GVHD $(104,105)$. However, there is an increased risk of chronic GVHD in patients who survive acute GVHD (101). Children have a better outcome than adults after HCT and this is striking in patients with severe acute GVHD (6). In a prospective randomized study performed by Osiris, it was reported that children treated for severe acute GVHD, as opposed to adults, had a better outcome (51). The first multicenter study using MSCs for acute GVHD also showed a better outcome in children than adults (47). However, this was not supported by a meta-analysis, which showed that survival following MSC therapy for acute GVHD did not differ in children and adults (106).

An advantage of using MSCs as opposed to other drugs to treat acute GVHD is safety, with few, if any side-effects $(107,108)$. There were no side-effects caused by the stromal cells in any of the six children treated with DSCs.

The ideal source of stromal cell for treatment of acute GVHD, MSC from bone marrow, adipose tissue, Wharton's jelly, umbilical cord, placenta tissue or DSCs, may be discussed. In a humanized mouse model, it was shown that MSCs from $\mathrm{BM}$, umbilical cord, and adipose tissue had different properties (109). In Table 3 is listed the different properties of MSCs from bone marrow compared to DSCs. Bone marrow aspiration is quite a painful procedure. Thus, alternative sources such as adipose tissue, cord, placenta tissue, or fetal membrane, stromal cells are more easily accessible. We found that DSCs had a stronger immunosuppression of alloreactivity in vitro in mixed lymphocyte cultures compared to MSCs from other 
TABLE 3 | Differences between bone marrow-derived mesenchymal stromal cells and placenta-derived decidual stromal cells.

\begin{tabular}{lcc}
\hline Characteristic & MSC & DSC \\
\hline Expansion potential & ++ & ++++ \\
Differentiation to fat and cartilage & +++ & $+/$ \\
Size, volume & 4600 fl & $2400 \mathrm{fl}$ \\
Express PDL-1, PDL-2 & + & ++ \\
Express CD49d, homing to inflammatory tissue (integrin) & + & ++ \\
Vascular cell adhesion molecule 1 (VCAM-1) expression & + & - \\
Express HLA class II after IFN $\gamma$ stimulation & + & - \\
Pro-coagulant tissue factor & $6 \%$ & $39 \%$ \\
CD55 complement regulatory activity & $62 \%$ & $98 \%$ \\
Reduction in clotting time & $55 \%$ & $70 \%$ \\
Prevent alloreactivity in vitro (MLC) & ++ & +++ \\
Needs direct contact for immunosuppression & - & + \\
Overall response in steroid refractory acute GVHD & $75 \%$ & $100 \%$ \\
\hline MLC, mixed lymphocyte culture & &
\end{tabular}

MLC, mixed lymphocyte culture.

sources. We therefore selected DSCs for further investigation (30). DSCs also appeared to be more effective for treating acute GVHD compared to BM-MSCs (69). However, it is unlikely that different sources of stromal cells will be compared in prospective randomized studies for the treatment of acute GVHD. Currently, there are several promising drugs for treating acute GVHD, such as Ruxolitinib, Vedolizumab and Etanercept (110-112). However, it seems that an advantage of using MSCs is the toxicity profile.

The first child (UPN1555) was treated with G-CSF for poor engraftment. G-CSF was reported to be associated with severe acute GVHD because it can trigger alloreactive Tcells $(113,114)$. G-CSF may have potentiated acute GVHD in this child.

Several large studies have been using MSCs, as shown from a single report on children from Kurtzberg et al. who recently reported on 241 children with grade II-IV steroid refractory acute GVHD (115). The 28-day overall response rate was $65 \%$ with a $14 \%$ complete response. The 100 -day survival was $67 \%$. These results were achieved with the commercially available MSCs Remestemcel-L. The randomized study by Osiris, which did not show an overall improvement in the placebo-controlled trial, showed that pediatric patients had a significantly better outcome using MSCs compared to the placebo group (53). Bonig et al. used MSCs pooled from multiple donors to treat acute GVHD (58). They reported an overall response rate of $82 \%$ following a median of three doses of pooled MSCs. Overall, 6-month survival was $64 \%$.

MSCs have mainly been used for treatment of acute GVHD in pediatric patients. They have not been used much for chronic GVHD. This is because stromal cells have a strong anti-inflammatory effect, which may be more effective for acute inflammatory processes such as acute GVHD and less effective in chronic fibrotic processes (116). Another indication for MSCs, mainly used in adults, is hemorrhagic cystitis $(117,118)$. MSCs have also been used for the treatment of acute respiratory distress syndrome (ARDS). There is a wealth of experimental data suggesting the potential of MSCs for sepsis and ARDS (119-121).
We treated a young boy who developed ARDS after HCT with MSCs (122). He died from massive Aspergillus infection. DSCs were shown to dramatically reverse ARDS in a male patient early after HCT (123). There is limited clinical experience (124). The lack of data on pediatric patients for these more novel indications could be because they are under development. If effective in the adult studies, MSCs will also be used for hemorrhagic cystitis, ARDS, and other indications that are more experimental today.

In addition to acute GVHD, MSCs have also been used to prevent and reverse graft failure, enhance engraftment, or as prophylaxis to reduce GVHD (74, 79-81). These studies include pediatric patients and adults.

As discussed above, the immunosuppressive effects of MSCs are induced by direct contact, as well as via several soluble factors. Exosomes and microvesicles derived from MSCs were shown to protect from acute kidney injury (125), myocardial ischemia (126), and pulmonary hypotension (127) in animal models. Exosomes for MSCs were also demonstrated to reverse severe acute GVHD (46). Since exosomes will only transfer soluble effect by MSCs and not a direct immunosuppressive effect, it is less likely that exosomes will replace MSCs in the near future.

To conclude, MSCs from various sources are mainly used in pediatric patients to treat severe acute GVHD and have shown encouraging response rates and survival efficacy. Thus, commercially available MSCs are registered as a drug in Canada, Japan and New Zeeland (128). Furthermore, MSCs also have the potential to cure other acute inflammatory and toxic disorders seen in pediatric patients, such as hemorrhages, ARDS, poor engraftment, and possibly also neuroinflammatory disorders (129).

\section{DATA AVAILABILITY STATEMENT}

The datasets presented in this article are not readily available because There is no restriction for the authors of this article to use this datasets. However it is not publicly available. The reviewers are of course welcome to request any data they feel are of importance for evaluating the study properly. Requests to access the datasets should be directed to Olle.ringden@ki.se; Britt.Gustafsson@ki.se.

\section{ETHICS STATEMENT}

The studies involving human participants were reviewed and approved by Ethical committee of Karolinska Institutet, Stockholm, Sweden. Approval to collect placentas and isolate decidual stromal cells (DSC), Dnr 20019/413-31/4 and 2010/2061-32. To use DSCs for treatment of acute GVHD and toxicity after hematopoietic cell transplantation (Dnr 2010/452-31/4 and 2014/2132-32). Written informed consent to participate in this study was provided by the participants' legal guardian/next of kin.

\section{AUTHOR CONTRIBUTIONS}

$\mathrm{OR}, \mathrm{BG}$, and BS: concept and design, collection and assembly of data, manuscript writing, and final approval of manuscript. $\mathrm{OR}$ and BG: financial support. $\mathrm{OR}$ and BS: administrative 
support. All authors contributed to the article and approved the submitted version.

\section{FUNDING}

This study was supported by grants from the Swedish Cancer Foundation CAN 2018, 419 and the Cancer Society in Stockholm

\section{REFERENCES}

1. Simpson E, Dazzi F. Bone marrow transplantation 1957-2019. Front Immunol. (2019) 10:1246. doi: 10.3389/fimmu.2019.01246

2. Thomas ED, Buckner CD, Banaji M, Clift RA, Fefer A, Flournoy N, et al. One hundred patients with acute leukemia treated by chemotherapy, total body irradiation, and allogeneic marrow transplantation. Blood. (1977) 49:511-33. doi: 10.1182/blood.V49.4.511.511

3. Storb R, Prentice RL, Thomas ED. Treatment of aplastic anemia by marrow transplantation from HLA identical siblings. prognostic factors associated with graft versus host disease and survival. J Clin Invest. (1977) 59:625-32. doi: 10.1172/JCI108680

4. Hoogerbrugge PM, Brouwer OF, Bordigoni P, Ringden O, Kapaun P, Ortega $\mathrm{JJ}$, et al. Allogeneic bone marrow transplantation for lysosomal storage diseases. the European group for bone marrow transplantation. Lancet. (1995) 345:1398-402. doi: 10.1016/S0140-6736(95)92597-X

5. Storb R, Deeg HJ, Pepe M, Appelbaum F, Anasetti C, Beatty P, et al. Methotrexate and cyclosporine versus cyclosporine alone for prophylaxis of graft-versus-host disease in patients given HLA-identical marrow grafts for leukemia: long-term follow-up of a controlled trial. Blood. (1989) 73:172934. doi: 10.1182/blood.V73.6.1729.1729

6. Ringden O, Nilsson B. Death by graft-versus-host disease associated with HLA mismatch, high recipient age, low marrow cell dose, and splenectomy. Transplantation. (1985) 40:39-44. doi: 10.1097/00007890-19850700000009

7. Mårtensson T, Szakos A, Mellgren K, Toporski J, Arvidson J, Casswall $\mathrm{TH}$, et al. Choice of endoscopic procedure in children with clinically suspected gastrointestinal graft-versus-host disease. J Pediatr Gastroenterol Nutr. (2018) 66:744-50. doi: 10.1097/MPG.0000000000001776

8. Mårtensson T, Mellgren K, Toporski J, Arvidson J, Szakos A, Casswall TH, et al. Clinical relevance of endoscopy with histopathological assessment in children with suspected gastrointestinal graft-versus-host disease. Clin Transplant. (2020) 5:e13867. doi: 10.1111/ctr.13867

9. Mårtensson T, Szakos A, Mellgren K, Toporski J, Arvidson J, Mattsson J, et al. Diagnostic disagreement between clinical standard histopathological-, and retrospective assessment of histopathology-based gastrointestinal graftversus-host disease in children. Pediatr Transpl. (2020) 1-5.

10. Groth CG GG, Lundgren G, Moller E, Pihlstedt P, Ringden O Sundelin P. Successful treatment with prednisone and graft-versus-host disease in an allogeneic bone marrow transplant recipient. Scand J Haematol. (1979) 22:333-8. doi: 10.1111/j.1600-0609.1979.tb00428.x

11. Martin PJ, Inamoto Y, Flowers ME, Carpenter PA. Secondary treatment of acute graft-versus-host disease: a critical review. Biol Blood Marrow Transplant. (2012) 18:982-8. doi: 10.1016/j.bbmt.2012.04.006

12. Friedenstein AJ, Petrakova KV, Kurolesova AI, Frolova GP. Heterotopic of bone marrow. analysis of precursor cells for osteogenic and hematopoietic tissues. Transplantation. (1968) 6:230-47. doi: 10.1097/00007890-196803000-00009

13. Le Blanc K, Rasmusson I, Sundberg B, Gotherstrom C, Hassan M, Uzunel $\mathrm{M}$, et al. Treatment of severe acute graft-versus-host disease with third party haploidentical mesenchymal stem cells. Lancet. (2004) 363:1439-41. doi: 10.1016/S0140-6736(04)16104-7

14. Ringden O, Uzunel M, Rasmusson I, Remberger M, Sundberg B, Lonnies $\mathrm{H}$, et al. Mesenchymal stem cells for treatment of therapyresistant graft-versus-host disease. Transplantation. (2006) 81:1390-7. doi: 10.1097/01.tp.0000214462.63943.14
(111293). OR was the recipient of a Distinguished Professor Award from the Karolinska Institutet.

\section{ACKNOWLEDGMENTS}

We would like to thank Gunilla Tillinger for her excellent work in typing this manuscript.

15. Haynesworth SE, Baber MA, Caplan AI. Cell surface antigens on human marrow-derived mesenchymal cells are detected by monoclonal antibodies. Bone. (1992) 13:69-80. doi: 10.1016/8756-3282(92)90363-2

16. Pittenger MF, Mackay AM, Beck SC, Jaiswal RK, Douglas R, Mosca JD, et al. Multilineage potential of adult human mesenchymal stem cells. Science. (1999) 284:143-7. doi: 10.1126/science.284.5411.143

17. Le Blanc K, Tammik C, Rosendahl K, Zetterberg E, Ringden O. HLA expression and immunologic properties of differentiated and undifferentiated mesenchymal stem cells. Exp Hematol. (2003) 31:890-6. doi: 10.1016/S0301-472X(03)00110-3

18. Koc ON, Gerson SL, Cooper BW, Dyhouse SM, Haynesworth SE, Caplan AI, et al. Rapid hematopoietic recovery after coinfusion of autologousblood stem cells and culture-expanded marrow mesenchymal stem cells in advanced breast cancer patients receiving high-dose chemotherapy. J Clin Oncol. (2000) 18:307-16. doi: 10.1200/JCO.2000.18.2.307

19. Bartholomew A, Sturgeon C, Siatskas M, Ferrer K, McIntosh K, Patil S, et al. Mesenchymal stem cells suppress lymphocyte proliferation in vitro and prolong skin graft survival in vivo. Exp Hematol. (2002) 30:42-8. doi: 10.1016/S0301-472X(01)00769-X

20. Di Nicola M, Carlo-Stella C, Magni M, Milanesi M, Longoni PD, Matteucci P, et al. Human bone marrow stromal cells suppress T-lymphocyte proliferation induced by cellular or nonspecific mitogenic stimuli. Blood. (2002) 99:383843. doi: 10.1182/blood.V99.10.3838

21. Le Blanc K, Tammik L, Sundberg B, Haynesworth SE, Ringdén O. Mesenchymal stem cells inhibit and stimulate mixed lymphocyte cultures and mitogenic responses independently of the major histocompatibility complex. Scand J Immunol. (2003) 57:11-20. doi: 10.1046/j.1365-3083.2003.01176.x

22. Moll G, Jitschin R, von Bahr L, Rasmusson-Duprez I, Sundberg B, Lonnies $\mathrm{L}$, et al. Mesenchymal stromal cells engage complement and complement receptor bearing innate effector cells to modulate immune responses. PLoS ONE. (2011) 6:e21703. doi: 10.1371/journal.pone.0021703

23. Li Y, Lin F. Mesenchymal stem cells are injured by complement after their contact with serum. Blood. (2012) 120:3436-43. doi: 10.1182/blood-2012-03-420612

24. Morando S, Vigo T, Esposito M, Casazza S, Novi G, Principato MC, et al. The therapeutic effect of mesenchymal stem cell transplantation in experimental autoimmune encephalomyelitis is mediated by peripheral and central mechanisms. Stem Cell Res Ther. (2012) 3:3. doi: 10.1186/scrt94

25. Keating A. Mesenchymal stromal cells: new directions. Cell Stem Cell. (2012) 10:709-16. doi: 10.1016/j.stem.2012.05.015

26. Nauta AJ, Fibbe WE. Immunomodulatory properties of mesenchymal stromal cells. Blood. (2007) 110:3499-506. doi: 10.1182/blood-2007-02-069716

27. Le Blanc K, Ringden O. Immunobiology of human mesenchymal stem cells and future use in hematopoietic stem cell transplantation. Biol Blood Marrow Transplant. (2005) 11:321-34. doi: 10.1016/j.bbmt.2005.01.005

28. Cheung TS, Dazzi F. Mesenchymal-myeloid interaction in the regulation of immunity. Semin Immunol. (2018) 35:59-68. doi: 10.1016/j.smim.2018.01.002

29. Tse WT, Pendleton JD, Beyer WM, Egalka MC, Guinan EC. Suppression of allogeneic T-cell proliferation by human marrow stromal cells: implications in transplantation. Transplantation. (2003) 75:389-97. doi: 10.1097/01.TP.0000045055.63901.A9

30. Karlsson H, Erkers T, Nava S, Ruhm S, Westgren M, Ringden O. Stromal cells from term fetal membrane are highly suppressive in 
allogeneic settings in vitro. Clin Exp Immunol. (2012) 167:543-55. doi: 10.1111/j.1365-2249.2011.04540.x

31. Jones S, Horwood N, Cope A, Dazzi F. The antiproliferative effect of mesenchymal stem cells is a fundamental property shared by all stromal cells. J Immunol. (2007) 179:2824-31. doi: 10.4049/jimmunol.179.5.2824

32. Aggarwal S, Pittenger MF. Human mesenchymal stem cells modulate allogeneic immune cell responses. Blood. (2005) 105:1815-22. doi: 10.1182/blood-2004-04-1559

33. Selmani Z, Naji A, Gaiffe E, Obert L, Tiberghien P, Rouas-Freiss N, et al. HLA-G is a crucial immunosuppressive molecule secreted by adult human mesenchymal stem cells. Transplantation. (2009) 87(9 Suppl.):S62-6. doi: 10.1097/TP.0b013e3181a2a4b3

34. Gieseke F, Bohringer J, Bussolari R, Dominici M, Handgretinger R, Muller I. Human multipotent mesenchymal stromal cells use galectin-1 to inhibit immune effector cells. Blood. (2010) 116:3770-9. doi: 10.1182/blood-2010-02-270777

35. Meisel R, Zibert A, Laryea M, Gobel U, Daubener W, Dilloo D. Human bone marrow stromal cells inhibit allogeneic T-cell responses by indoleamine 2,3dioxygenase-mediated tryptophan degradation. Blood. (2004) 103:4619-21. doi: 10.1182/blood-2003-11-3909

36. Ge W, Jiang J, Arp J, Liu W, Garcia B, Wang H. Regulatory T-cell generation and kidney allograft tolerance induced by mesenchymal stem cells associated with indoleamine 2,3-dioxygenase expression. Transplantation. (2010) 90:1312-20. doi: 10.1097/TP.0b013e3181fed001

37. Francois M, Romieu-Mourez R, Li M, Galipeau J. Human MSC suppression correlates with cytokine induction of indoleamine 2,3-dioxygenase and bystander M2 macrophage differentiation. Mol Ther. (2012) 20:187-95. doi: $10.1038 / \mathrm{mt} .2011 .189$

38. Augello A, Tasso R, Negrini SM, Amateis A, Indiveri F, Cancedda R, et al. Bone marrow mesenchymal progenitor cells inhibit lymphocyte proliferation by activation of the programmed death 1 pathway. Eur J Immunol. (2005) 35:1482-90. doi: 10.1002/eji.200425405

39. Ren G, Zhao X, Zhang L, Zhang J, L'Huillier A, Ling W, et al. Inflammatory cytokine-induced intercellular adhesion molecule-1 and vascular cell adhesion molecule-1 in mesenchymal stem cells are critical for immunosuppression. J Immunol. (2010) 184:2321-8. doi: 10.4049/jimmunol.0902023

40. Saldanha-Araujo F, Ferreira FI, Palma PV, Araujo AG, Queiroz RH, Covas DT, et al. Mesenchymal stromal cells up-regulate CD39 and increase adenosine production to suppress activated T-lymphocytes. Stem Cell Res. (2011) 7:66-74. doi: 10.1016/j.scr.2011.04.001

41. Akiyama $\mathrm{K}$, Chen $\mathrm{C}$, Wang $\mathrm{D}, \mathrm{Xu} \mathrm{X}, \mathrm{Qu} \mathrm{C}$, Yamaza $\mathrm{T}$, et al. Mesenchymal-stem-cell-induced immunoregulation involves FAS-ligand/FAS-mediated T cell apoptosis. Cell Stem Cell. (2012) 10:544-55. doi: $10.1016 / j . s t e m .2012 .03 .007$

42. Sadeghi B, Ringden O. Mesenchymal stem cells for graft-versus-host disease in experimental animal models. In: Gross G, Haupl T, editors. Stem CellDependent Therapies-Mesenchymal Stem Cells in Chronic Inflammatory Disorders. Berlin: Walter de Gruyter GmbH (2013). p. 125-42.

43. Parekkadan B, Upadhyay R, Dunham J, Iwamoto Y, Mizoguchi E, Mizoguchi A, et al. Bone marrow stromal cell transplants prevent experimental enterocolitis and require host CD11b+ splenocytes. Gastroenterology. (2011) 140:966-75. doi: 10.1053/j.gastro.2010.10.013

44. Galleu A, Riffo-Vasquez Y, Trento C, Lomas C, Dolcetti L, Cheung TS, et al. Apoptosis in mesenchymal stromal cells induces in vivo recipient-mediated immunomodulation. Sci Transl Med. (2017) 9:eaam7828. doi: $10.1126 /$ scitranslmed.aam7828

45. Thery C, Ostrowski M, Segura E. Membrane vesicles as conveyors of immune responses. Nat Rev Immunol. (2009) 9:581-93. doi: 10.1038/nri2567

46. Kordelas L, Rebmann V, Ludwig AK, Radtke S, Ruesing J, Doeppner TR, et al. MSC-derived exosomes: a novel tool to treat therapy-refractory graft-versushost disease. Leukemia. (2014) 28:970-3. doi: 10.1038/leu.2014.41

47. Le Blanc K, Frassoni F, Ball L, Locatelli F, Roelofs H, Lewis I, et al. Mesenchymal stem cells for treatment of steroid-resistant, severe, acute graft-versus-host disease: a phase II study. Lancet. (2008) 371:1579-86. doi: 10.1016/S0140-6736(08)60690-X

48. Fang B, Song Y, Lin Q, Zhang Y, Cao Y, Zhao RC, et al. Human adipose tissuederived mesenchymal stromal cells as salvage therapy for treatment of severe refractory acute graft-vs.-host disease in two children. Pediatr Transplant. (2007) 11:814-7. doi: 10.1111/j.1399-3046.2007.00780.x

49. Lucchini G, Introna M, Dander E, Rovelli A, Balduzzi A, Bonanomi S, et al. Platelet-lysate-expanded mesenchymal stromal cells as a salvage therapy for severe resistant graft-versus-host disease in a pediatric population. Biol Blood Marrow Transplant. (2010) 16:1293-301. doi: 10.1016/j.bbmt.2010.03.017

50. Prasad VK, Lucas KG, Kleiner GI, Talano JA, Jacobsohn D, Broadwater G, et al. Efficacy and safety of ex vivo cultured adult human mesenchymal stem cells (Prochymal) in pediatric patients with severe refractory acute graft-versus-host disease in a compassionate use study. Biol Blood Marrow Transplant. (2011) 17:534-41. doi: 10.1016/j.bbmt.2010.04.014

51. Martin PJ, Uberti JP, Soiffer RJ, Klingemann H, Waller EK, Daly AS, et al. Prochymal improves response rates in patients with steroidrefractory acute graft versus host disease (SR-GVHD) involving the liver and gut: results of a randomized, placebo-controlled, multicenter phase III trial in GVHD. Biol Blood Marrow Transplant. (2010) 16:S169-70. doi: 10.1016/j.bbmt.2009.12.057

52. Kebriaei P, Hayes J, Daly A, Uberti J, Marks DI, Soiffer R, et al. A phase 3 randomized study of remestemcel-L versus placebo added to second-line therapy in patients with steroid-refractory acute graftversus-host disease. Biol Blood Marrow Transplant. (2020) 26:835-44. doi: 10.1016/j.bbmt.2019.08.029

53. Szabolcs P, Visani G, Locatelli F, Kleiner G, Talano J, Nemecek E, et al. Treatment of steroid-refractory acute GVHD with mesenchymal stem cells improves outcomes in pediatric patients; results of the pediatric subset in a phase III randomized, placebo-controlled study. Biol Blood Marrow Transplant. (2010) 16:S298. doi: 10.1016/j.bbmt.2009.12.426

54. Ball LM, Bernardo ME, Roelofs H, van Tol MJ, Contoli B, Zwaginga JJ, et al. Multiple infusions of mesenchymal stromal cells induce sustained remission in children with steroid-refractory, grade III-IV acute graft-versus-host disease. Br J Haematol. (2013) 163:501-9. doi: 10.1111/bjh.12545

55. Kurtzberg J, Abdel-Azim H, Carpenter P, Chaudhury S, Horn B, Mahadeo $\mathrm{K}$, et al. A phase 3, single-arm, prospective study of remestemcel-l, ex vivo culture-expanded adult human mesenchymal stromal cells for the treatment of pediatric patients who failed to respond to steroid treatment for acute graft-versus-host disease. Biol Blood Marrow Transplant. (2020) 26:845-54. doi: 10.1016/j.bbmt.2020.01.018

56. Dotoli GM, De Santis GC, Orellana MD, de Lima Prata K, Caruso SR, Fernandes TR, et al. Mesenchymal stromal cell infusion to treat steroidrefractory acute GvHD III/IV after hematopoietic stem cell transplantation. Bone Marrow Transplant. (2017) 52:859-62. doi: 10.1038/bmt. 2017.35

57. Salmenniemi U, Itälä-Remes $M$, Nystedt J, Putkonen M, Niittyvuopio R, Vettenranta K, et al. Good responses but high TRM in adult patients after MSC therapy for GvHD. Bone Marrow Transplant. (2017) 52:606-8. doi: 10.1038/bmt.2016.317

58. Bonig H, Kuci Z, Kuci S, Bakhtiar S, Basu O, Bug G, et al. Children and adults with refractory acute graft-versus-host disease respond to treatment with the mesenchymal stromal cell preparation "MSC-FFM" -outcome report of 92 patients. Cells. (2019) 8. doi: 10.3390/cells8121577

59. Kuçi Z, Bönig H, Kreyenberg H, Bunos M, Jauch A, Janssen JW, et al. Mesenchymal stromal cells from pooled mononuclear cells of multiple bone marrow donors as rescue therapy in pediatric severe steroid-refractory graftversus-host disease: a multicenter survey. Haematologica. (2016) 101:985-94. doi: 10.3324/haematol.2015.140368

60. von Bahr L, Sundberg B, Lönnies L, Sander B, Karbach H, Hägglund $\mathrm{H}$, et al. Long-term complications, immunologic effects, and role of passage for outcome in mesenchymal stromal cell therapy. Biol Blood Marrow Transplant. (2012) 18:557-64. doi: 10.1016/j.bbmt.2011. 07.023

61. Wernicke CM, Grunewald TG, Hendrik J, Kuci S, Kuci Z, Koehl U, et al. Mesenchymal stromal cells for treatment of steroid-refractory GvHD: a review of the literature and two pediatric cases. Int Arch Med. (2011) 4:27. doi: $10.1186 / 1755-7682-4-27$

62. Morata-Tarifa C, Macías-Sánchez MDM, Gutiérrez-Pizarraya A, SanchezPernaute R. Mesenchymal stromal cells for the prophylaxis and treatment of graft-versus-host disease-a meta-analysis. Stem Cell Res Ther. (2020) 11:64. doi: $10.1186 / s 13287-020-01592-z$ 
63. Ringdén O DH. Clinical spectrum of graft-versus-host disease. In: Ferrara JLM DH, Burakoff S, editors. Graft vs Host Disease. New York, NY: Marcel Dekker (1996). p. 525-59.

64. Sullivan KM, Shulman HM, Storb R, Weiden PL, Witherspoon RP, McDonald GB, et al. Chronic graft-versus-host disease in 52 patients: adverse natural course and successful treatment with combination immunosuppression. Blood. (1981) 57:267-6. doi: 10.1182/blood.V57.2.267.267

65. Parekkadan B, Tilles AW, Yarmush ML. Bone marrow-derived mesenchymal stem cells ameliorate autoimmune enteropathy independently of regulatory T cells. Stem Cells. (2008) 26:1913-9. doi: 10.1634/stemcells.20070790

66. Sun L, Akiyama K, Zhang H, Yamaza T, Hou Y, Zhao S, et al. Mesenchymal stem cell transplantation reverses multiorgan dysfunction in systemic lupus erythematosus mice and humans. Stem Cells. (2009) 27:1421-32. doi: $10.1002 /$ stem. 68

67. Weng JY, Du X, Geng SX, Peng YW, Wang Z, Lu ZS, et al. Mesenchymal stem cell as salvage treatment for refractory chronic GVHD. Bone Marrow Transplant. (2010) 45:1732-40. doi: 10.1038/bmt.2010. 195

68. Pérez-Simon JA, López-Villar O, Andreu EJ, Rifón J, Muntion S, Diez Campelo $\mathrm{M}$, et al. Mesenchymal stem cells expanded in vitro with human serum for the treatment of acute and chronic graft-versus-host disease: results of a phase I/II clinical trial. Haematologica. (2011) 96:1072-6. doi: 10.3324/haematol.2010.038356

69. Ringden O, Baygan A, Remberger M, Gustafsson B, Winiarski J, Khoein $B$, et al. Placenta-derived decidua stromal cells for treatment of severe acute graft-versus-host disease. Stem Cells Transl Med. (2018) 7:325-31. doi: 10.1002/sctm.17-0167

70. Erkers T, Kaipe H, Nava S, Mollden P, Gustafsson B, Axelsson R, et al. Treatment of severe chronic graft-versus-host disease with decidual stromal cells and tracing with (111)indium radiolabeling. Stem Cells Dev. (2015) 24:253-63. doi: 10.1089/scd.2014.0265

71. Filipovich AH, Weisdorf D, Pavletic S, Socie G, Wingard JR, Lee SJ, et al. National institutes of health consensus development project on criteria for clinical trials in chronic graft-versus-host disease: I. diagnosis and staging working group report. Biol Blood Marrow Transplant. (2005) 11:945-56. doi: 10.1016/j.bbmt.2005.09.004

72. Chung NG, Jeong DC, Park SJ, Choi BO, Cho B, Kim HK, et al. Cotransplantation of marrow stromal cells may prevent lethal graft-versushost disease in major histocompatibility complex mismatched murine hematopoietic stem cell transplantation. Int J Hematol. (2004) 80:370-6. doi: 10.1532/IJH97.A30409

73. Lazarus HM, Koc ON, Devine SM, Curtin P, Maziarz RT, Holland HK, et al. Cotransplantation of HLA-identical sibling culture-expanded mesenchymal stem cells and hematopoietic stem cells in hematologic malignancy patients. Biol Blood Marrow Transplant. (2005) 11:389-98. doi: 10.1016/j.bbmt.2005.02.001

74. Le Blanc K, Samuelsson H, Gustafsson B, Remberger M, Sundberg B, Arvidson J, et al. Transplantation of mesenchymal stem cells to enhance engraftment of hematopoietic stem cells. Leukemia. (2007) 21:1733-8. doi: $10.1038 /$ sj.leu.2404777

75. Ning $\mathrm{H}$, Yang $\mathrm{F}$, Jiang $\mathrm{M}, \mathrm{Hu} \mathrm{L}$, Feng $\mathrm{K}$, Zhang $\mathrm{J}$, et al. The correlation between cotransplantation of mesenchymal stem cells and higher recurrence rate in hematologic malignancy patients: outcome of a pilot clinical study. Leukemia. (2008) 22:593-9. doi: 10.1038/sj.leu. 2405090

76. Baron F, Lechanteur C, Willems E, Bruck F, Baudoux E, Seidel L, et al. Cotransplantation of mesenchymal stem cells might prevent death from graft-versus-host disease (GVHD) without abrogating graft-versustumor effects after HLA-mismatched allogeneic transplantation following nonmyeloablative conditioning. Biol Blood Marrow Transplant. (2010) 16:838-47. doi: 10.1016/j.bbmt.2010.01.011

77. Gonzalo-Daganzo R, Regidor C, Martín-Donaire T, Rico MA, Bautista G, Krsnik I, et al. Results of a pilot study on the use of third-party donor mesenchymal stromal cells in cord blood transplantation in adults. Cytotherapy. (2009) 11:278-88. doi: 10.1080/1465324090 2807018
78. Macmillan ML, Blazar BR, DeFor TE, Wagner JE. Transplantation of exvivo culture-expanded parental haploidentical mesenchymal stem cells to promote engraftment in pediatric recipients of unrelated donor umbilical cord blood: results of a phase I-II clinical trial. Bone Marrow Transplant. (2009) 43:447-54. doi: 10.1038/bmt.2008.348

79. Ball LM, Bernardo ME, Roelofs H, Lankester A, Cometa A, Egeler $\mathrm{RM}$, et al. Cotransplantation of ex vivo expanded mesenchymal stem cells accelerates lymphocyte recovery and may reduce the risk of graft failure in haploidentical hematopoietic stem-cell transplantation. Blood. (2007) 110:2764-7. doi: 10.1182/blood-2007-04087056

80. Meuleman N, Tondreau T, Ahmad I, Kwan J, Crokaert F, Delforge A, et al. Infusion of mesenchymal stromal cells can aid hematopoietic recovery following allogeneic hematopoietic stem cell myeloablative transplant: a pilot study. Stem Cells Dev. (2009) 18:1247-52. doi: 10.1089/scd.2009. 0029

81. Ringdén O. Mesenchymal stromal cells as first-line treatment of graft failure after hematopoietic stem cell transplantation. Stem Cells Dev. (2009) 18:1243-6. doi: 10.1089/scd.2009.1809.edi

82. Hobbs JR. Bone marrow transplantation for inborn errors. Lancet. (1981) 2:735-9. doi: 10.1016/S0140-6736(81)91059-X

83. Groth CG, Ringdén $\mathrm{O}$. Transplantation in relation to the treatment of inherited disease. Transplantation. (1984) 38:319-27. doi: 10.1097/00007890-198410000-00001

84. Koç ON, Peters C, Aubourg P, Raghavan S, Dyhouse S, DeGasperi R, et al. Bone marrow-derived mesenchymal stem cells remain host-derived despite successful hematopoietic engraftment after allogeneic transplantation in patients with lysosomal and peroxisomal storage diseases. Exp Hematol. (1999) 27:1675-81. doi: 10.1016/S0301-472X(99)00101-0

85. Horwitz EM, Prockop DJ, Fitzpatrick LA, Koo WW, Gordon PL, Neel $\mathrm{M}$, et al. Transplantability and therapeutic effects of bone marrow-derived mesenchymal cells in children with osteogenesis imperfecta. Nat Med. (1999) 5:309-13. doi: $10.1038 / 6529$

86. Le Blanc K, Götherström C, Ringdén O, Hassan M, McMahon $\mathrm{R}$, Horwitz E, et al. Fetal mesenchymal stem-cell engraftment in bone after in utero transplantation in a patient with severe osteogenesis imperfecta. Transplantation. (2005) 79:1607-14. doi: 10.1097/01.TP.0000159029.48678.93

87. Ringden O, Uzunel M, Sundberg B, Lonnies L, Nava S, Gustafsson J, et al. Tissue repair using allogeneic mesenchymal stem cells for hemorrhagic cystitis, pneumomediastinum and perforated colon. Leukemia. (2007) 21:2271-6. doi: $10.1038 /$ sj.leu.2404833

88. Moll G, Ignatowicz L, Catar R, Luecht C, Sadeghi B, Hamad O, et al. Different procoagulant activity of therapeutic mesenchymal stromal cells derived from bone marrow and placental decidua. Stem Cells Dev. (2015) 24:2269-79. doi: $10.1089 / \mathrm{scd} .2015 .0120$

89. Yin F, Battiwalla M, Ito S, Feng X, Chinian F, Melenhorst JJ, et al. Bone marrow mesenchymal stromal cells to treat tissue damage in allogeneic stem cell transplant recipients: correlation of biological markers with clinical responses. Stem Cells. (2014) 32:1278-88. doi: 10.1002/stem. 1638

90. Remberger M, Svahn BM, Mattsson J, Ringdén O. Dose study of thymoglobulin during conditioning for unrelated donor allogeneic stem-cell transplantation. Transplantation. (2004) 78:122-7.

91. Storb R, Thomas ED. Graft-versus-host disease in dog and man: the Seattle experience. Immunol Rev. (1985) 88:215-38. doi: 10.1111/j.1600-065X.1985.tb01160.x

92. Mattsson J, Uzunel M, Remberger M, Ringdén O. T cell mixed chimerism is significantly correlated to a decreased risk of acute graft-versus-host disease after allogeneic stem cell transplantation. Transplantation. (2001) 71:433-9. doi: 10.1097/00007890-200102150-00017

93. Ljungman P, Aschan J, Lewensohn-Fuchs I, Carlens S, Larsson $\mathrm{K}$, Lönnqvist B, et al. Results of different strategies for reducing cytomegalovirus-associated mortality in allogeneic stem cell transplant recipients. Transplantation. (1998) 66:1330-4. doi: 10.1097/00007890-199811270-00012

94. Sundin M, Le Blanc K, Ringdén O, Barkholt L, Omazic B, Lergin C, et al. The role of HLA mismatch, splenectomy and recipient Epstein-Barr virus 
seronegativity as risk factors in post-transplant lymphoproliferative disorder following allogeneic hematopoietic stem cell transplantation. Haematologica. (2006) 91:1059-67.

95. Calkoen FG, Vervat C, van Halteren AG, Welters MJ, Veltrop-Duits LA, Lankester AC, et al. Mesenchymal stromal cell therapy is associated with increased adenovirus-associated but not cytomegalovirus-associated mortality in children with severe acute graft-versus-host disease. Stem Cells Transl Med. (2014) 3:899-910. doi: 10.5966/sctm.2013-0191

96. Ringden O, Erkers T, Nava S, Uzunel M, Iwarsson E, Conrad R, et al. Fetal membrane cells for treatment of steroid-refractory acute graftversus-host disease. Stem Cells. (2013) 31:592-601. doi: 10.1002/stem. 1314

97. Ringden O, Åhstrom L, Lönnqvist B, Båryd I, Svedmyr E, Gahrton G. Allogeneic bone marrow transplantation in a patient with chemotherapy-resistant progressive histiocytosis. N Engl J Med. (1987) 316:733-5.

98. Ringdén O, Lönnqvist B, Holst M. Twelve-year-follow-up of the first allogeneic bone marrow transplantation for Langerhan's cell histiocytosis. Lancet. (1997) 349:476.

99. Toft N, Birgens H, Abrahamsson J, Griškevičius L, Hallböök H, Heyman $\mathrm{M}$, et al. Results of NOPHO ALL2008 treatment for patients aged 145 years with acute lymphoblastic leukemia. Leukemia. (2018) 32:606-15. doi: $10.1038 /$ leu.2017.265

100. Sadeghi B, Remberger M, Gustafsson B, Winiarski J, Moretti G, Khoein B, et al. Long-term follow-up of a pilot study using placenta-derived decidua stromal cells for severe acute graft-versus-host disease. Biol Blood Marrow Transplant. (2019) 25:1965-9. doi: 10.1016/j.bbmt.2019.05.034

101. Ringdén O, Labopin M, Sadeghi B, Mailhol A, Beelen D, Fløisand Y, et al. What is the outcome in patients with acute leukaemia who survive severe acute graft-versus-host disease? J Intern Med. (2018) 283:166-77. doi: $10.1111 /$ joim. 12695

102. Horowitz MM, Gale RP, Sondel PM, Goldman JM, Kersey J, Kolb HJ, et al. Graft-versus-leukemia reactions after bone marrow transplantation. Blood. (1990) 75:555-62. doi: 10.1182/blood.V75.3.555.bloodjournal 753555

103. Ringdén O, Labopin M, Gluckman E, Reiffers J, Vernant JP, Jouet JP, et al. Graft-versus-leukemia effect in allogeneic marrow transplant recipients with acute leukemia is maintained using cyclosporin A combined with methotrexate as prophylaxis. acute leukemia working party of the European group for blood and marrow transplantation. Bone Marrow Transplant. (1996) 18:921-9.

104. Ringdén O, Paulin T, Lönnqvist B, Nilsson B. An analysis of factors predisposing to chronic graft-versus-host disease. Exp Hematol. (1985) 13:1062-7.

105. Storb R, Prentice RL, Sullivan KM, Shulman HM, Deeg HJ, Doney KC, et al. Predictive factors in chronic graft-versus-host disease in patients with aplastic anemia treated by marrow transplantation from HLAidentical siblings. Ann Int Med. (1983) 98:461-6. doi: 10.7326/0003-4819-984-461

106. Hashmi S, Ahmed M, Murad MH, Litzow MR, Adams RH, Ball LM, et al. Survival after mesenchymal stromal cell therapy in steroid-refractory acute graft-versus-host disease: systematic review and meta-analysis. Lancet Haematol. (2016) 3:e45-52. doi: 10.1016/S2352-3026(15)00224-0

107. Lalu MM, McIntyre L, Pugliese C, Fergusson D, Winston BW, Marshall JC, et al. Safety of cell therapy with mesenchymal stromal cells (SafeCell): a systematic review and meta-analysis of clinical trials. PLoS ONE. (2012) 7:e47559. doi: 10.1371/journal.pone.0047559

108. Thompson M, Mei SHJ, Wolfe D, Champagne J, Fergusson D, Stewart DJ, et al. Cell therapy with intravascular administration of mesenchymal stromal cells continues to appear safe: An updated systematic review and meta-analysis. EClinicalMedicine. (2020) 19:100249. doi: 10.1016/j.eclinm.2019.100249

109. Grégoire C, Ritacco C, Hannon M, Seidel L, Delens L, Belle L, et al. Comparison of mesenchymal stromal cells from different origins for the treatment of graft-vs.-host-disease in a humanized mouse model. Front Immunol. (2019) 10:619. doi: 10.3389/fimmu.2019.00619

110. Zeiser R, Burchert A, Lengerke C, Verbeek M, Maas-Bauer K, Metzelder SK, et al. Ruxolitinib in corticosteroid-refractory graft-versus-host disease after allogeneic stem cell transplantation: a multicenter survey. Leukemia. (2015) 29:2062-8. doi: 10.1038/leu.2015.212

111. Fløisand Y, Lundin KEA, Lazarevic V, Kristiansen JD, Osnes LTN, Tjønnfjord GE, et al. Targeting integrin $\alpha 4 \beta 7$ in steroid-refractory intestinal graftversus-host disease. Biol Blood Marrow Transplant. (2017) 23:172-5. doi: 10.1016/j.bbmt.2016.10.009

112. Faraci M, Calevo MG, Giardino S, Leoni M, Ricci E, Castagnola E, et al. Etanercept as treatment of steroid-refractory acute graft-versus-host disease in pediatric patients. Biol Blood Marrow Transplant. (2019) 25:743-8. doi: 10.1016/j.bbmt.2018.11.017

113. Ringden O, Labopin M, Gorin NC, Le Blanc K, Rocha V, Gluckman E, et al. Treatment with granulocyte colony-stimulating factor after allogeneic bone marrow transplantation for acute leukemia increases the risk of graft-versushost disease and death: a study from the acute leukemia working party of the european group for blood and marrow transplantation. J Clin Oncol. (2004) 22:416-23. doi: 10.1200/JCO.2004.06.102

114. Morris ES, MacDonald KP, Kuns RD, Morris HM, Banovic T, Don AL, et al. Induction of natural killer T cell-dependent alloreactivity by administration of granulocyte colony-stimulating factor after bone marrow transplantation. Nat Med. (2009) 15:436-41. doi: 10.1038/nm.1948

115. Kurtzberg J, Prockop S, Chaudhury S, Horn B, Nemecek E, Prasad V, et al. Study 275: updated expanded access program for remestemcel-l in steroidrefractory acute graft-versus-host disease in children. Biol Blood Marrow Transplant. (2020) 26:855-64. doi: 10.1016/j.bbmt.2020.01.026

116. Ringden O, Keating A. Mesenchymal stromal cells as treatment for chronic GVHD. Bone Marrow Transplant. (2011) 46:163-4. doi: 10.1038/bmt.2010.275

117. Ringdén O, Leblanc K. Pooled MSCs for treatment of severe hemorrhage. Bone Marrow Transplant. (2011) 46:1158-60. doi: 10.1038/bmt. 2010.262

118. Ringden O, Le Blanc K. Mesenchymal stem cells for treatment of acute and chronic graft-versus-host disease, tissue toxicity and hemorrhages. Best Pract Res Clin Haematol. (2011) 24:65-72. doi: 10.1016/j.beha.2011.01.003

119. Lee JW, Rocco PR, Pelosi P. Mesenchymal stem cell therapy for acute respiratory distress syndrome: a light at the end of the tunnel? Anesthesiology. (2015) 122:238-40. doi: 10.1097/ALN.0000000000000546

120. Laffey JG, Matthay MA. Fifty Years of Research in ARDS. Cell-based therapy for acute respiratory distress syndrome. biology and potential therapeutic value. Am J Respir Crit Care Med. (2017) 196:266-73. doi: 10.1164/rccm.201701-0107CP

121. Wang J, Loh SW, Lee JH. Paediatric acute respiratory distress syndrome: progress over the past decade. J Emerg Crit Care Med. (2018) 2. doi: $10.21037 /$ jeccm.2018.02.04

122. Ringdén O. Mesenchymal stem (stromal) cells for treatment of acute respiratory distress syndrome. Lancet Respir Med. (2015) 3:24-32. doi: 10.1016/S2213-2600(15)00047-8

123. Ringden $O$, Solders $M$, Erkers $T$, Nava S, Molldén P, Hultcrantz $\mathrm{M}$, et al. Successful reversal of acute lung injury using placentaderived decidual stromal cells. J Stem Cell Res Ther. (2014) 4:1-5. doi: 10.4172/2157-7633.1000244

124. Matthay MA, Calfee CS, Zhuo H, Thompson BT, Wilson JG, Levitt JE, et al. Treatment with allogeneic mesenchymal stromal cells for moderate to severe acute respiratory distress syndrome (START study): a randomised phase 2a safety trial. Lancet Respir Med. (2019) 7:154-62. doi: 10.1016/S2213-2600(18)30418-1

125. Bruno S, Grange C, Collino F, Deregibus MC, Cantaluppi V, Biancone L, et al. Microvesicles derived from mesenchymal stem cells enhance survival in a lethal model of acute kidney injury. PLOS ONE. (2012) 7:e33115. doi: 10.1371/journal.pone.0033115

126. Lai RC, Arslan F, Lee MM, Sze NS, Choo A, Chen TS, et al. Exosome secreted by MSC reduces myocardial ischemia/reperfusion injury. Stem Cell Res. (2010) 4:214-22. doi: 10.1016/j.scr.2009.12.003

127. Lee C, Mitsialis SA, Aslam M, Vitali SH, Vergadi E, Konstantinou G, et al. Exosomes mediate the cytoprotective action of mesenchymal stromal cells on hypoxia-induced pulmonary hypertension. Circulation. (2012) 126:2601-11. doi: 10.1161/CIRCULATIONAHA.112.114173

128. Allison M. NCATS launches drug repurposing program. Nat Biotechnol. (2012) 30:571-2. doi: 10.1038/nbt0712-571a 
129. Sadeghi B, Ersmark B, Moretti G, Mattsson J, Ringdén O. Treatment of radiculomyelopathy in two patients with placenta-derived decidua stromal cells. Int J Hematol. (2020) 111:591-4. doi: 10.1007/s12185-019-02804-w

Conflict of Interest: The authors declare that the research was conducted in the absence of any commercial or financial relationships that could be construed as a potential conflict of interest.
Copyright $\odot 2020$ Ringdén, Gustafsson and Sadeghi. This is an open-access article distributed under the terms of the Creative Commons Attribution License (CC BY). The use, distribution or reproduction in other forums is permitted, provided the original author(s) and the copyright owner(s) are credited and that the original publication in this journal is cited, in accordance with accepted academic practice. No use, distribution or reproduction is permitted which does not comply with these terms. 